\title{
Encouraging Economic Development Through Local Community Participation in Sidoarjo, Indonesia
}

\author{
$1^{\text {st }}$ Imamul Huda Al Siddiq \\ Universitas Negeri Malang \\ Malang, Indonesia \\ imamul.huda.fis@um.ac.id \\ $2^{\text {nd }}$ Agung Winarno \\ Universitas Negeri Malang \\ Malang, Indonesia agung.winaro.fe@um.ac.id
}

\author{
$3^{\text {rd }}$ Idris \\ Universitas Negeri Malang \\ Malang, Indonesia \\ idris.fis@um.ac.id \\ $4^{\text {th }}$ Ronal Ridhoi \\ Universitas Negeri Malang \\ Malang, Indonesia ronal.ridhoi.fis@um.ac.id
}

\begin{abstract}
The 1998 economic crisis that occurred in Indonesia witnessed history that the informal economy such as MSMEs proved to be able to survive in the midst of a storm of crisis. Therefore, economic growth through the development of MSME products is quite glimpsed by the public. In addition to not needing large capital, MSMEs also have relatively small risks. This article aims to discuss the participation of local people in the development of MSME leather products in Kedensari Village, Tanggulangin Sub-District, Sidoarjo Regency in disruption era. This study uses Mixed Method as the research method with the Sequential Exploratory research approach. This research approach places qualitative methods as the main method, and quantitative methods as supporting methods. This study will describe the participation of local people in developing MSMEs with Arnstein's theory of participation. Based on the theory, community participation is divided by level from Citizen control, Delegated Power, Partnership, Placation, Consultation, Informing, Therapy, and Manipulation. The participation of the Kedensari village local community regarding the development of MSME leather products will be classified based on the classification of participation from the Arnstein theory.
\end{abstract}

Keywords: participation of local communities, MSMEs, disruption era, leather products, Arnstein

\section{INTRODUCTION}

One of the efforts in village development is economic development as the implementation of one of the indicators of the Sustainable Development Goal (SDG's), ending all forms of poverty [1]. The economic aspect is a central aspect in people's lives because it involves meeting the basic needs of the community. Strengthening the economic sector is inevitable an important part of policy formulation from the central government to the lowest government. As the development of the world economy, industrialization is increasingly massive, making the existence of MSME increasingly vital in society. MSMEs are proven to be able to survive and sustain the economy of the Indonesian people in the midst of the current economic crisis that once hit in 1998 [2]. Based on the 2012 economic census report, the number of MSMEs in Indonesia is 56,534,592 out of $56,539,560$ units in the number of entrepreneurs. That is, $99.9 \%$ of businesses in Indonesia are micro and small scale businesses [2]. The report shows how SMEs are the backbone of the Indonesian people's economy. In fact, SMEs are able to become the largest contributor to GRDP in East Java [3].

In East Java, MSMEs are one of the mainstay programs of the Provincial Government to improve the economy of the community. Based on the MSME census conducted in 2012 there were 6,825,931 MSMEs in East Java. Of these there are 6.5 million MSMEs which are micro-scale businesses dominated by informal businesses which have limited assets, access and productivity, 261,827 are small scale and the remaining 30,410 are medium-scale businesses (East Java Cooperative and SME Office, 2017). This number is increasing as the next period economic census report conducted in 2016. The economic census carried out in 2016 noted that the number of MSMEs has increased with details of 4.61 million Non-Agricultural MSMEs and 4.98 Million MSMEs, amounting to 9, 59 million MSMEs[4].

With such a large number of MSMEs, the hope and foundation of East Java's economy through the MSME sector is very large. Because of this, all elements of society have a large share in the development of the economic sector. In this case, the role of the village government, as the political elite at the grassroots level is very calculated. The Central 
Government through the Ministry of Villages, Development of Disadvantaged Areas, and Transmigration for example has formulated several programs aimed at increasing the capacity of village governments in developing economic aspects such as the BUMDesa strengthening and development program, Community-Based Community Economic Business Development, and village market revitalization (DG PPMD, 2018). Unfortunately, the program has not been implemented optimally. Based on the Ministry of Trade's Directorate General of PPMD's performance report for 2017 shows the target of BUMDesa development for example, which is targeted at 1200 villages, only 940 villages have been realized.

Thus the role of the village government and also the local community in developing local potential in the village has a significant influence. The village government and the local community are the spearheads in community empowerment. Local potentials in the village can be managed by the community and returned to the community as well. The concept of building from below is probably very relevant in this context. the welfare of a country starts from the welfare of the people in each village. So that the role of the village government together with the local community is expected to have considerable significance in village development. Especially, the enactment of law No. 6 of 2014 increasingly confirmed the position of village government in village management. Thus, the role of the village government is very large in the development of the local economic sector through the development of these MSMEs. Thus researchers are interested in seeing how the political process of village government policy and the participation of local communities in the development of local potential MSMEs that exist in villages in East Java.

Research on MSMEs has actually been done a lot. For example the research conducted by Szabo \& Petrosyan [5] with the title Small and medium-sized enterprises in the Caucasian countries in transition examines how the condition of MSMEs in the area inhabited by Caucasians in the transition period. The area is experiencing a transition to free market areas. This study looked at the condition of MSMEs in the Caucasian region during the transition period. He provides information about the characteristics of existing MSMEs, and steps taken by the government to develop MSMEs. The study found that the macroeconomic framework and conditions in the caucasian region were still not profitable for MSME development areas, the transformation towards the market economy was still not possible. The study examines the ecology between the socio-political conditions in the region or country inhabited by the caucasian race and its economic conditions specifically in the development of MSMEs.

The development of MSMEs has also been studied in relation to the role and position of women in society by Naidu
\& Chand [6] with the title National Culture, Gender Inequality and Women's Success in Micro, Small and Medium Enterprises. They researched in the Republic of Fiji Islands and found that (1) gender inequality is a major barrier to the success of women in micro, small and medium enterprises (MSMEs), (2) national culture is positively related to barriers faced by women entrepreneurs, (3) barriers women entrepreneurs face negatively related to the success of women entrepreneurs in micro, small and medium enterprises, (4) national culture is negatively related to the success of women entrepreneurs in micro, small and medium enterprises and (5) culture moderates the relationship between gender inequality and successful women in micro, small and medium enterprises.

While the research from Ersi and Samuel [7] with the title of CRM Analysis, Customer Satisfaction and SME Product Loyalty Based on Flour Raw Materials in East Java is also worth mentioning here. The study examines how the CRM (Customer Relationship Management) strategy in developing MSMEs is able to provide stimuli to customer satisfaction and loyalty towards these MSME products. This study found that the CRM method has a positive influence on customer satisfaction and customer satisfaction has an influence on consumer loyalty to products made by flour-based SMEs in East Java. This study examines the effect of certain stimuli on creating consumer satisfaction and loyalty towards MSME products in East Java.

Research from Kurniawati \& Mukzam [8] with the title Implementation and Impact of PT Pelabuhan Indonesia III (Persero) Partnership and Community Development Program in the development of MSMEs actually examined the role of one part of the government in developing MSMEs, but he only examined the role of BUMN in efforts developing MSMEs through the initiated partnership program. This research found that PKBL activities (PT Pelindo III's Partnership and Community Development Program that have been made since 2003 as a form of corporate responsibility towards the community have had a positive impact especially for the community to assist the government in implementing programs that can improve welfare, especially in the field of This study focuses on the analysis of Pelindo III's PKBL internal program activities in MSME development programs It was found that in the PKBL process related to the MSME development program, many deviations that occurred such as monitoring the PKBL program were not optimal, MSME entrepreneurs who do not implement recommendations from the PKBL committee in financial management.

The three studies above have not yet examined the role of village governments and local communities and no one has examined the use of local potential in the development of MSMEs. The government's role in developing MSMEs has actually been reviewed by Putri [9] with the title of Implementation of the Implementation of Micro, Small and 
Medium Enterprises (MSME) Development Programs in Samarinda City (Study at Samarinda City Cooperative and UMKM Office), but the study examines the role of the city government in this case the government of the city of Samarinda, has not studied the role of the village government. The study found that the Government of Samarinda City has an important role in the development of MSMEs through training, empowerment, socialization, guidance and supervision programs for MSME actors.

Although the city / district government is the same as the village government, the city government has a wide range, and has not been able to touch the community at the lowest level as well as the village government. The village government is one of the elements of the government that is able to touch the community to its roots. So that in fact the spearhead of community empowerment is the village government. However, it cannot be denied that the village government cannot stand alone in managing village potential in its area. He still needs to synergize with the existing government at a higher level to succeed the national programs in the village. Vice versa, the central and regional governments also need to synergize with the village government, especially in the management of local resources in the village.

Local potentials in the village, is a feasible potential to be developed, one of which is through the MSME development program. The economic development program based on local potential or resources has been studied before [10], [11] Herlin \& Basri researched the models and strategies of leading creative industry-based MSME development based on local potential in Jambi City. Whereas Winarno et. al. Researching the management of tourism potential based on local potential in Malang Regency.

Herlin \& Basri [10] focus on identifying the creative industry-based MSMEs that have the potential to be developed, how the creative industry-based MSME development model is based on local potential and how the policies taken by the Jambi City government relate to the development of creative industry-based MSMEs the local potential. This study found that firstly, the creative potential industry based on local potential in Jambi City which has advantages to be developed is the handicraft, design, fashion, film, video and photography industries, the interactive game industry, publishing and printing industry, and television and the radio industry. Second, the creative industry-based model of MSME development based on local potential must pay attention to efforts to increase workforce creativity through formal education, training and through wage levels, which will have a positive impact on the development of MSME creative industries.

Whereas Winarno [11] focuses on mapping based on the idea of building tourist villages based on sustainable local potential in Sumberagung and Pait Villages in North Malang Regency. This study found that there was considerable potential in the area related to productive economy that could be developed sustainably by developing eco-tourism and socio-cultural community support.

The research of Herlin \& Basri [10] and Winarno [11] above researched the development of productive economy based on existing local potential. Herlin \& Basri [10] in addition to examining the utilization of local potential in the development of MSMEs, he also examined the role of local governments in developing these MSMEs. However, the research conducted by Herlin \& Basri is in the Jambi City area, different from this research conducted in East Java Province. While Winarno [11] conducted research related to the utilization of local potential for the development of productive economies in Malang Regency. Winarno [11] has not mentioned the role of local government in developing productive economies, especially in the MSME sector. Only, he mentioned a little about how autonomous village formation through the development of local potential tourism villages.

\section{LITERATURE REVIEW}

\section{A. Regional Autonomy}

Since the introduction of regional autonomy through the Republic of Indonesia's MPR Decree Number XV / MPR / 1998 concerning the Implementation of Regional Autonomy, Regulating, Distributing and Utilizing Equitable National Resources, and balancing the Central and Regional Finance in the NKRI Framework, as well as a set of laws on the implementation of autonomy regions, each region has full authority in the management and development of its territory. At the village level, the autonomy authority was confirmed by the enactment of Law No. 6 of 2014 concerning Villages.

Regional autonomy, especially at the village level, has certain implications for village management. Village governments can be more effective and efficient in village management, however, the costs incurred by the government are also higher. Honest and responsible governance behavior and active community involvement in village development also become calculated parameters. When a village government does not have an adequate self-financing mechanism, the village government will be entirely too dependent on funding from the center and the regions. Therefore, through law no. 6 of 2014 concerning villages, the village government was given the freedom to manage the APBDes. The village government must be able to optimize all existing village income potentials to prosper the community without having to add to the burden on the community [12].

\section{B. Theory of Community Participation}

In terminology in a large Indonesian dictionary, participation is defined as participation and participation of a person or group of people in an activity. In the context of 
quantitative approaches [16] to obtain data that is more comprehensive, valid, reliable, and objective [17]. This approach is needed to answer the proposed problem formulation. A qualitative approach is needed to explore deeply the problems of the political process of village government policies in developing MSMEs based on local potential and quantitative approaches to address the problem of local community participation in the development of MSMEs based on local potential. Both of these approaches were carried out in order to find the problems that occurred in the development process carried out by the village government as well as to provide a new understanding of the involvement of local communities in the process of developing MSMEs based on local potential in East Java.

Data collection, technically, uses Sequential Exploratory techniques, namely by collecting and analyzing qualitative data first, then the next step is collecting and analyzing quantitative data [16]. Sequential Exploratory was chosen as an approach model in collecting data to show the priority of the research method used was more qualitative, that is by making the results of quantitative data analysis as a support for qualitative data analysis [16]. Data collection is done by interviewing, observing, and documenting the research object [18]. While in the next stage, data analysis used in this study uses a data analysis model [19] which consists of data collection, data reduction, data presentation, and conclusion drawing.

This research will be conducted in Sidoarjo and Blitar Districts using Purposive Sampling as a sampling technique. This technique is used in order to choose samples based on research objectives [17]. Sidoarjo and Blitar districts were chosen as research objects with several reasons including: the two districts have the highest number of home industry-based MSMEs in East Java [20], the potential of local resourcebased MSMEs is one of the superior products of each region and each of these regions makes MSMEs the backbone of regional economic growth.

To ascertain whether the measuring instrument used to measure the level of community participation in MSME development programs is calculated the validity and reliability of research instruments whose results can be seen below table I.

\section{METHOD}

This research uses a combination method or mix method, which is a research approach that combines qualitative and 
TABLE I. THE RESULTS OF THE VALIDITY AND RELIABILITY OF THE RESEARCH INSTRUMENT

\begin{tabular}{|c|c|c|c|c|c|c|}
\hline \multirow[b]{2}{*}{ No. } & \multirow[b]{2}{*}{ STATEMENTS } & \multirow[b]{2}{*}{$r$ table } & \multicolumn{2}{|c|}{ Validitity } & \multicolumn{2}{|c|}{ Reliability } \\
\hline & & & Spearman & Inf. & $\begin{array}{l}\text { Cronbach's } \\
\text { Alpha }\end{array}$ & Inf. \\
\hline 1 & $\begin{array}{l}\text { I always participate in formulating workplan in the } \\
\text { village }\end{array}$ & 0,296 & 0,88 & Valid & 0,931 & Consistence \\
\hline 2 & $\begin{array}{l}\text { I always participate in formulating programs for the } \\
\text { development of MSMEs in the village }\end{array}$ & 0,296 & 0,928 & Valid & 0,928 & Consistence \\
\hline 3 & $\begin{array}{l}\text { I always participate in village planning meetings } \\
\text { related to the development of MSMEs }\end{array}$ & 0,296 & 0,915 & Valid & 0,929 & Consistence \\
\hline 4 & I always participate in every village activity & 0,296 & 0,738 & Valid & 0,939 & Consistence \\
\hline 5 & $\begin{array}{l}\text { I always attend the MSME development program } \\
\text { socialization from the village government }\end{array}$ & 0,296 & 0,814 & Valid & 0,935 & Consistence \\
\hline 6 & $\begin{array}{l}\text { I always take self-development training related to } \\
\text { the development of MSMEs }\end{array}$ & 0,296 & 0,9 & Valid & 0,93 & Consistence \\
\hline 7 & $\begin{array}{l}\text { I always receive MSME capital financing from any } \\
\text { party, especially from the village }\end{array}$ & 0,296 & 0,649 & Valid & 0,943 & Consistence \\
\hline 8 & I always participate in evaluating village activities & 0,296 & 0,784 & Valid & 0,937 & Consistence \\
\hline 9 & $\begin{array}{l}\text { I always participate in evaluating MSME } \\
\text { development programs }\end{array}$ & 0,296 & 0,867 & Valid & 0,932 & Consistence \\
\hline 10 & $\begin{array}{l}\text { I always participate in the use of development for } \\
\text { MSMEs }\end{array}$ & 0,296 & 0,58 & Valid & 0,946 & Consistence \\
\hline
\end{tabular}

\section{RESULTS AND DISCUSSION}

This study found several facts relating to the participation of local communities in the village MSME development program. There are several indicators used to measure the extent of community participation in participating in developing MSMEs in their villages. These indicators included participation in the formulation of village work programs, participation in village government MSME development programs, participation in village planning meetings related to MSME development, participation in each village activity, participation in the dissemination of village MSME development, participation in self-development training related to development MSMEs, participation in receiving funding for MSME capital, participation in village activity program evaluations, participation in evaluation of village MSME development programs, participation in the use of development outcomes related to the development of MSMEs.

TABLE II. FREQUENCY DISTRIBUTION

\begin{tabular}{|c|c|c|c|c|c|c|c|}
\hline No. & STATEMENTS & $\begin{array}{l}\text { Strongly } \\
\text { Disagree }\end{array}$ & Disagree & Agree & $\begin{array}{l}\text { Strongly } \\
\text { Agree }\end{array}$ & Total & Mean \\
\hline & & 1 & 2 & 3 & 4 & & \\
\hline 1 & $\begin{array}{l}\text { I always participate in formulating workplan in the } \\
\text { village }\end{array}$ & 9 & 31 & 33 & 2 & 75 & 2,37 \\
\hline 2 & $\begin{array}{l}\text { I always participate in formulating programs for the } \\
\text { development of MSMEs in the village }\end{array}$ & 11 & 33 & 28 & 3 & 75 & 2,31 \\
\hline 3 & $\begin{array}{l}\text { I always participate in village planning meetings } \\
\text { related to the development of MSMEs }\end{array}$ & 12 & 33 & 27 & 3 & 75 & 2,28 \\
\hline 4 & I always participate in every village activity & 7 & 25 & 38 & 5 & 75 & 2,55 \\
\hline 5 & $\begin{array}{l}\text { I always attend the MSME development program } \\
\text { socialization from the village government }\end{array}$ & 11 & 37 & 23 & 4 & 75 & 2,27 \\
\hline 6 & $\begin{array}{l}\text { I always take self-development training related to the } \\
\text { development of MSMEs }\end{array}$ & 15 & 32 & 25 & 3 & 75 & 2,21 \\
\hline 7 & $\begin{array}{l}\text { I always receive MSME capital financing from any } \\
\text { party, especially from the village }\end{array}$ & 16 & 43 & 14 & 2 & 75 & 2,03 \\
\hline 8 & I always participate in evaluating village activities & 12 & 33 & 28 & 2 & 75 & 2,27 \\
\hline 9 & $\begin{array}{l}\text { I always participate in evaluating MSME development } \\
\text { programs }\end{array}$ & 13 & 32 & 28 & 2 & 75 & 2,25 \\
\hline 10 & $\begin{array}{l}\text { I always participate in the use of development for } \\
\text { MSMEs }\end{array}$ & 6 & 38 & 29 & 2 & 75 & 2,36 \\
\hline
\end{tabular}


to the statement was 2.28 . The index obtained is certainly still far from the ideal participation index.

\section{A. Participation in the Formulation of Village Work Programs}

Participation in the formulation of village work programs is used as an indicator considering this participation is quite important. Village communities who participated in the village program planning process, he would most likely be involved in village programs. In the statement I always participate in the formulation of village work programs, there are $12 \%$ of respondents strongly disagree, $41.33 \%$ of respondents disagree, $44 \%$ of respondents answered agree and the remaining $2.67 \%$ of respondents answered strongly agree. From the pattern of visible data, the majority of respondents answered disagree and agreed. The data is then made a scale with a scale of 4 for answers strongly agree, scale 3 for answers agree, scale 2 for answers disagree and scale 1 for answers strongly disagree.

The attitude index for the statement "I always participate in the formulation of village work programs" of 2.63 with a maximum scale of 4 . Scale of this size shows how participation in the formulation of village work programs by the community is still being. The community has not participated maximally in the formulation of village work programs.

\section{B. Participation in the Formulation of Village MSME Development Programs}

In this section, it is measured how community participation is specifically in the formulation of village MSME development programs. Of the 75 respondents who expressed their attitude to the statement "I always participate in the formulation of village government MSME development programs" $14.7 \%$ answered strongly disagree, $44 \%$ answered disagree, $37.3 \%$ answered agreed, and $4 \%$ answered agreed.

The table above shows an overview of community participation in the formulation of the Kedensari village MSME development program in Sidoarjo Regency. The index that appears on the attitude of respondents to the statement "I always participate in the formulation of village government MSME development programs" is 2.31. This figure is still said to be quite low.

\section{Participation in Village Planning Meetings Relates to the Development of MSMEs.}

Community participation in village planning meetings related to the development of MSMEs was measured by the attitude of respondents to the statement "I always participate in village planning meetings related to the development of MSMEs". For the statement, there were as many as $16 \%$ answered strongly disagree, $44 \%$ of respondents answered disagree, $36 \%$ of respondents answered agreed and as many as $4 \%$ of respondents agreed to the statement. The mean obtained for the number of respondents who gave an attitude

\section{Participation in Each Village Activity}

The participation of the Kedensari Village community in the dissemination of MSME development programs is still fairly low, with an index of 2.27. Participation in this socialization is measured by the attitude of respondents to the statement "I always follow the socialization of MSME development programs from the village government". Of the 75 respondents who answered there were $14.7 \%$ answered strongly disagree, $49.3 \%$ answered disagree, $30.7 \%$ answered agreed, and $5.3 \%$ answered strongly agree.

\section{E. Participation in MSME Training}

Respondents' participation in MSME training was measured by the attitude of respondents to the statement "I always attend self-development training related to the development of MSMEs". The participation index obtained from these measurements is 2.21 with a scale of 4 . With an index of 2.21, community participation in training related to the development of MSMEs is still very low. Of all respondents who answered strongly disagree with the statement above, there were $20 \%$ of respondents. $42.7 \%$ of respondents disagree, while $33.3 \%$ of respondents answered agree, and the remaining amount of $4 \%$ answered strongly agree.

\section{CONCLUSION}

From the quantitative data obtained can be drawn a conclusion that the participation of local people in the development of MSMEs is still fairly low. Of all respondents who answered the questionnaire the average level of participation ranged from 2.4. This number is relatively low compared to the maximum scale that should be available, namely 4. This needs further research what causes the participation of local communities in the development program of SMEs from the village is relatively low.

\section{REFERENCES}

[1] BPS, Kajian Indikator Sustainable Development Goals. Jakarta: Badan Pusat Statistik, 2014.

[2] Y. R. Suci, "Perkembangan UMKM (Usaha Mikro Kecil Dan Menengah) Di Indonesia," J. Ilm. Cano Ekon., vol. 6, no. 1, p. 8, 2017.

[3] S. H. Lestari, "Kontribusi UMKM ke PDRB Sangat Besar, Pemprov Jatim Target 27 Ribu UMKM Masuk Marketplace Digital,” Tribun Jatim, 19-Dec-2018. [Online]. Available: http://jatim.tribunnews.com/2018/12/19/kontribusi-umkm-ke-pdrbsangat-besar-pemprov-jatim-target-27-ribu-umkm-masukmarketplace-digital. [Accessed: 04-Jan-2019].

[4] Edi, "UMKM, Tulang Punggung Perekonomian Jawa Timur," Jatimprov.go.id, 22-Jun-2018. [Online]. Available: http://jatimprov.go.id/read/berita-pengumuman/umkm-tulangpunggung-perekonomian-jawa-timur. [Accessed: 23-Oct-2019] 
Tahun 2015," Polit. Indones. Indones. Polit. Sci. Rev., vol. 2, no. 1, p. 1, Jan. 2017.

[5] A. Szabó and A. Petrosyan, "Small and medium-sized enterprises in the Caucasian countries in transition," Asia Eur. J., vol. 5, no. 1, pp. 115-132, 2007.

[6] S. Naidu and A. Chand, "National Culture, Gender Inequality and Women's Success in Micro, Small and Medium Enterprises," Soc. Indic. Res., vol. 130, no. 2, pp. 647-664, 2017.

[7] D. Y. Ersi and H. Samuel, "Analysis CRM, Kepuasan Pelanggan Dan Loyalitas Produk UKM Berbasis Bahan Baku Terigu Di Jawa Timur," vol. 8, 2014.

[8] F. Kurniawati and M. D. Mukzam, "Pelaksanaan Dan Dampak Program Kemitraan Dan Bina Lingkungan PT Pelabuhan Indonesia III (Persero) Dalam Pengembangan UMKM," J. Adm. Bisnis JAB, vol. 50, no. 2, 2017.

[9] E. H. Putri, "Efektivitas Pelaksanaan Program Pengembangan Usaha Mikro Kecil Dan Menengah (UMKM) Di Kota Samarinda (Studi Pada Dinas Koperasi Dan UMKM Kota Samarinda)," EJournal Adm. Negara, vol. 5, 2017.

[10] F. Herlin and Basri, "Model Dan Strategi Pengembangan UMKM Industri Kreatif Unggulan Berbasis Potensi Lokal Di Kota Jambi," vol. 9, 2018.

[11] A. Winarno, T. Wijayanti, Y. Agustina, and Sopingi, "Pioneering an Autonomous Village Through the Management of Sustainable Tourism Village Based on Local Potential in Malang Regency," KnE Soc. Sci., vol. 3, no. 3, 2018.

[12] A. Setiawan, M. Haboddin, and N. F. Wilujeng, "Akuntabilitas Pengelolaan Dana Desa di Desa Budugsidorejo Kabupaten Jombang
[13] M. H. U. Dewi, "Pengembangan Desa Wisata Berbasis Partisipasi Masyarakat Lokal di Desa Wisata Jatiluwih Tabanan, Bali," vol. 3, no. 2, p. 11, 2013.

[14] C. Chaerunnissa, "Partisipasi Masyarakat dalam Program Penyediaan Air Minum dan Sanitasi Berbasis Masyarakat (PAMSIMAS) di Kabupaten Brebes," Politika, vol. 5, no. 2, 2014.

[15] S. R. Arnstein, “A Ladder Of Citizen Participation,” J. Am. Inst. Plann., vol. 35, no. 4, pp. 216-224, Jul. 1969.

[16] J. Creswell, Research design: pendekatan kualitatif, kuantitatif, dan mixed. Yogyakarta: Pustaka Pelajar, 2010.

[17] Sugiono, Metode Penelitian Kuantitatif, Kualitatif, dan R\&D, 26th ed. Bandung: Alfabeta, 2017.

[18] S. Arikunto, Prosedur Penelitian Suatu Pendekatan Praktik. Jakarta: Rineka Cipta, 2010.

[19] M. Miles and A. Haberman, Analisis Data Kualitatif. Jakarta: Penerbit UI, 1984.

[20] BPS East Java, Hasil Survei Pertanian Antar Sensus (SUTAS) 2018 Provinsi Jawa Timur. Jakarta: Badan Pusat Statistik Provinsi Jawa Timur, 2018. 